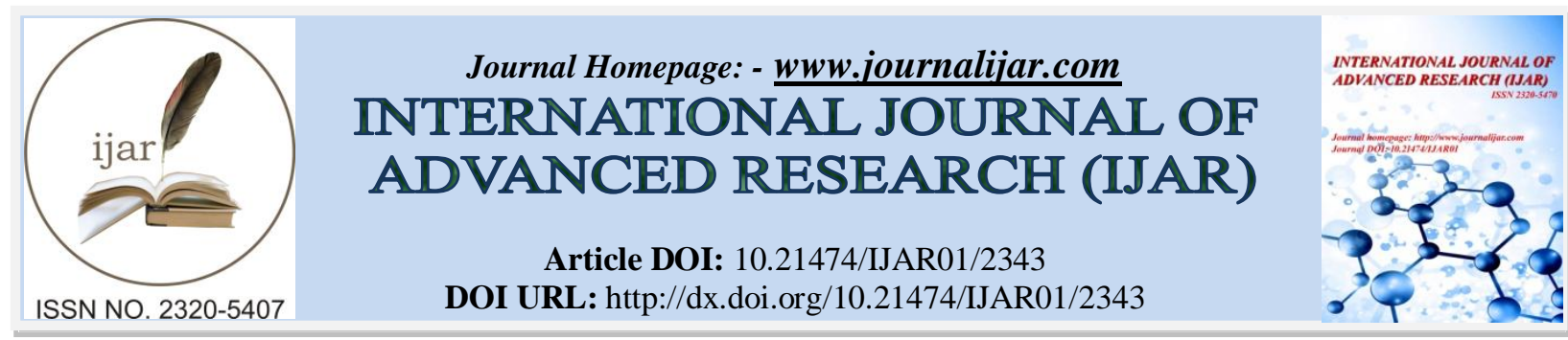

RESEARCH ARTICLE

\title{
DISTRIBUTION OF HYRAX (MAMMALIA/HYRACOIDEA/PROCAVIIDAE) IN THE CENTRAL REGIONS OF BENIN.
}

\section{"Daouda A. I. H. ${ }^{1}$, Adjanohoun M. ${ }^{1}$, Hennou A. ${ }^{1}$, Atindogbe G. ${ }^{2}$, Mensah G.A. ${ }^{3}$ and Sinsin B. ${ }^{4}$.}

1. Departement d'Amenagement and Gestion des Ressources Naturelles, Faculte d'Agronomie, Universite de Parakou (Benin).

2. Centre de Bio-statistique et Informatique Generale, Fac. Sc. Agronomiques, U.A.-C. Cotonou (Benin).

3. Institut National de Recherche Agronomique du Benin-INRAB / CRA - Agonkanmey, Cotonou (Benin).

4. Laboratoire d'Ecologie Appliquee/Fac. Sc. Agronomiques, Univ d'Abomey-Calavi (UA-C) Cotonou (Benin).

\section{Manuscript Info}

Manuscript History

Received: 30 September 2016

Final Accepted: 30 October 2016

Published: November 2016

Key words:-

Hyrax, central regions of Benin, distribution, Occurrence Area, Lama Forest.

\section{Abstract}

Few research works were carried out on hyraxes (family of Procaviidae) in Benin until now. This study provides the first data on the spatial distribution evolution of Procavia capensis (rock hyrax) and Dendrohyrax dorsalis subsp sylvestris (tree hyrax) in the central regions of Benin: if both kinds of hyrax are met in this area of Sudano Guinean transition, only Dendrohyrax dorsalis ssp. sylvestris are met in Guinea zone (South - Benin). In this phytogeographical area, the tree hyrax occupies essentially the Lama forest, and weakly met in few forest islands and in the valley of Oueme. The past and present occurrence areas of Dendrohyrax dorsalis subsp sylvestris were mapped and their surface area, calculated. Due to the significant fragmentation and degradation of habitat of tree hyrax in southern Benin, its occurrence areas increased from $8007 \mathrm{~km}^{2}$ to $4003 \mathrm{~km}^{2}$ (current occurrence area) within less than half a century. If the classified forest of Lama gathers the largest subpopulation, the other sites are severely fragmented, with small and isolated subpopulations in the forest islands far between them with a distance of dozens kilometers.

Copy Right, IJAR, 2016,. All rights reserved.

\section{Introduction:-}

According to IUCN (2009), $21 \%$ of mammals are considered endangered from the earth planet. Several cases have been recorded in African countries including Benin of which the red-bellied monkey Cercopithecus erythrogaster erythrogaster, endemic primate of Benin (Nobime and Sinsin, 2003; Sinsin et al., 2002). Similarly, some taxa continue to die out of Benin including Tragelaphus eurycerus (Neuenschwander et al., 2011); whereas several other taxa remain to be described or their taxonomic position may be indicated (Colyn et al., 2010; Granjon et al., 2005; Daouda, 2002; Codjia et al., 1996). This is the case of hyraxes which were a long time mistaken for rodents, but are now systematized in the particular order of Hyracoidea. From this order, its remains only the family of Procaviidae. From four species described initially, this number has now increased to eleven, divided into three genus: Procavia, Heterohyrax and Dendrohyrax. If the described species of these three genus of hyraxes were studied extensively in East Africa and South Africa, data is rare in the west part of the continent and particularly in Benin (Kingdon, 1997; Grubb, 1998; Bacho, 2004; Barry et al., 2008; Neuenschwander et al., 2011; Djossa et al., 2012; Daouda et al., 2015). From their works, it appears that two genus of hyrax are met in Benin: one species of the rock hyrax 
(Procavia, capensis, kerstingi) and one subspecies of tree hyrax, probably similar to the Dendrohyrax dorsalis ssp sylvestris described in Ghana as their vocalizations were concordant (Akpona et al., 2011). The country of Benin was excluded by omission from the occurrence area of tree hyrax until 2006 (Kingdon, 2006). Meanwhile genetic characterization of the tree hyrax in Benin, their geographic distribution area continues to be fragmented and reduced. This work presents the area of past and current occurrence of D. dorsalis ssp, and an estimation of its current occurrence area in Benin. Meanwhile genetic characterization of hyrax in Benin, their geographic range is constantly being reduced and fragmented. Also the geographic distribution of badgers in the Central regions of Benin, this work presents the past and current occurrence area of $D$. dorsalis subsp sylvestris in the south of Benin where the few dense forests islands (its preferred habitat) are highly degraded.

\section{Study Area:-}

The study was carried out in two out of three phyto-geographical areas of Benin (Figure 1), including the Guinean zone that extends from the coast to the Municipality of Djidja $\left(7^{\circ} 15 \mathrm{~N}\right)$, and the Guineo-Sudanese transition zone (ranges from $7^{\circ}-7^{\circ} 30 \mathrm{~N}$ to $9^{\circ} 30-10^{\circ} \mathrm{N}$ ). The preselected districts are presented in the study area (Figure 2). The first phytogeographical zone has a bimodal rainfall with $900 \mathrm{~mm}$ of rain per year in the western part to 1300 $\mathrm{mm} / \mathrm{year}$ in the East. This type of sub-equatorial climate is closely related to the phenomenon of "Dahomey Gap". Thus, if the semi-deciduous rainforest can still observe at a few forest Islands, "the evergreen unit of land is completely absent" (Neuenschwander et al., 2011; Sinsin et Kampmann, 2011).

Guinean area was divided into four phytogeographical districts namely the Coastal, the Oueme Valley, Pobè and Plateau (Adomou et al., 2006). Only the Oueme Valley, Pobè and Plateau phytogeographical districts were taken into account in the current work. The original vegetation is semi-deciduous dense forests and Guinean savannas. One can note the dense semi-deciduous rainforest made of Triplochiton scleroxylon and Celti zenkeri with some variations including the climatically dried Nesogordonia kabingaensis and Mansonia altissima, as swamp forest with Xylopia rubescens and Mitragyna ciliata and periodically flooded forest with Dialium guineense and Berlinia grandifolia (Oueme Valley). The forest of Lama that is seasonally flooded is rich in vegetable species such as Ceiba pentandra, Diospyros mespiliformis, Afzelia africana, Mimusop andongensis, Cynometra megalophylla, etc.

The vegetation of the Guinean-Congolese area is certainly very strongly deteriorated because of the high population density. The mammalian fauna of the Lama forest is composed of rodent species, reptile, cattle, small carnivores and primates (Sinsin and Assogbadjo, 2002; Kassa et al., 2007). The second study area (Guineo-Sudanian transition) is characterized by lower rainfall (1100 $\mathrm{mm}$ of rain per year) compared to the first, with a gradual merger of the two rainfall peaks, gradually as one leaves from its south limit to the north. The Guinean-Sudanese transition area is covered by granite hills and inselbergs and is divided into three phytogeographical districts: Zou, Bassila and South Borgou (Adomou et al., 2006).

In Zou phytogeographical District which is located in the south of the Guinean-Sudanese zone and adjacent to the Guinea-Congolese area, the climax vegetation is of dry deciduous forests type with Hildegardia barteri, Diospyros mespiliformis Pouteria alnifolia, Anogeissus leiocarpa, and some gallery forests.

The other two phytogeographic districts are essentially marked by the Classified Forests of Oueme, the Classified Forests of Wari-Maro, the Kouffé Mounts, the mounts of Agoua and Toui-Kilibo of Benin. The granite formations extend beyond the Guinean-Sudanese transition zone up to the extreme north of Benin (Sudanese zone).

\section{Materials And Methods:-}

It is to collect herein data to determine the geographic distribution of hyraxes in southern and central Benin. The method used was based on investigation through surveys and interviews and walking surveys. The populations targeted in investigations and interviews are hunters, forest rangers, local residents (including farmers, traditional healers) and any person resource of both sexes who can provide useful information and recognizing the hyraxes, their footprints, feces or their cries. Physiognomic planks and well-illustrated documents were enlisted to help the identification of the species. A questionnaire was administered to a sample of the target population, during group interviews and individual interviews with resource persons, for extra information. Furthermore, it was also collected skulls and / or body parts of hyraxes kept by hunters or other resource persons. The field study consisted of two phases: 
The first phase consisted of an initial investigation into nine administrative departments in the south and center of Benin (Atlantique, Mono, Couffo, Zou, Collines, Borgou, Donga, Plateau and Oueme valley). Thirty-six cities were preselected based on ecosystems and habitats they contain, even if hyraxes do not exist or have disappeared according to the documentation and resource persons. Then, 252 localities, both in villages, suburbs and hamlets were visited by the authors. 1548 people were interviewed respectively from October 2012, from January to February 2013, from April to May 2014 and from March to April 2015. This phase was followed by a phase of surveys, including potential sites of tree hyrax (known or inferred habitats, as well as the village lands or places mentioned in interviews). Sites (past and present) are georeferenced using GPS. Only sites or actual points of contact with the taxon (direct observation of the hyrax or recording of its cry) were qualified as current occupation sites.

The ArcGIS software was used for the treatment of geographic data for the design of the map of current and past occurrence areas of hyraxes. As exploration habitats is almost complete in the Guineo-Congolese area (southern part of Benin), the area of the previous range of occurrence and the area of current area were estimated using a digital electronic planimeter.

To describe the relationship between the knowledge of Daman by people, the kind of hyrax known and their respective habitats, according to their profession and administrative department, a Multiple Correspondence Analysis (MCA) was performed. The eight selected variables from the survey sheet for this analysis are presented in Table 1 with their respective variables. The MCA was performed using the statistical software 'R'.

\section{Results:-}

The main survey results are presented in Figures 4, 5, 6 and 7. A fraction of 20.5\%, or 318 individuals out of a total of 1548 people interviewed recognize at least one of the two taxa and their manners. However, this proportion varies greatly according to the Departments. The Department of Zou was the first (with 24\% of relative contribution), followed by the Cpollines (22\%) and Ouémé (14\%).

Axis 1 of the plane formed by the axes 1 and 2 opposes clearly the taxon rocks 'Proc' daytime habits ('Midi') to that tree hyrax 'Dend' often lonely 'soli' with nocturnal habits. This discrimination identifies the Departments associated exclusively with one of the 2 species or, relatively, to the both. The Departments Zou, Oueme, Plateau, Atlantic and Couffo are closely associated with tree taxon ('Dend') and are opposed, on axis 1, to the Departments Borgou, Donga and Collines which were dominates by the rock hyraxes. These three departments are in an intermediate position between the tree hyrax ('Dend') and the rock hyrax ('Proc'). However, they are nearer to the rock hyrax than tree hyrax. As for axis 2 which represents the sex and occupation, it combines the female ' $F$ ' to the profession of traditional therapist ('Trad'). This traditional therapist occupation is opposed to the other (farmer and hunter) dominated by men ('M').

Geographical boundaries map of the distribution of tree hyrax and rock hyrax (Fig. 5) highlights two areas of a large area of overlap. This sympatric area where both kinds of hyraxes have allotopic live, is entirely within the Sudano Guinean phyto-transition area. In the north of this central region as well as in the Sudan region (north - Benin), no rock hyrax (Procavia capensis) is met.

Tables 2 and 3 indicate the current occupation sites tree hyrax (Dendrohyrax dorsalis subsp sylvestris) respectively in the Guinean zone (southern part of Benin) and in the Sudano - Guinean transition zone (central regions of Benin). The 'site' of the Central Nucleus of the classified forest of Lama is designated by the plural ('sites') because it alone represents several stations or sites (Table 2). As in Table 3, it shows the presence of sites of $D$. dorsalis subsp sylvestris (five sites) identified in the central part of Benin which is the Sudano - Guinean transition zone; it is also the great sympatric area of the two genres of hyrax present in Benin.

In Figure 6, we see a site of rock hyrax (Procavia. Capensis), especially in the area of Kaodji, probably marking the beginning of its occurrence area which is located indeed at higher latitudes (Figure 7). It may be noted on the map that past occurrence area of Dendrohyrax dorsalis subsp sylvestris extends along the border with Nigeria.

If we extract from the map in Figure 8 the both sites of tree hyraxes located at the intersection of the Guinean zone and the Sudano - Guinean (Kaodji and Okpa), it would be only five current sites and two past sites of tree hyrax to fifteen current sites and ten past sites for rock hyraxes. 


\section{Discussion:-}

The percentage of interviewees who recognize at least one of the two taxa by the Department, is even lower than the species is rare. The Zou had recorded the highest percentage $(24 \%)$ because the forest of the Lama is the only habitat of the tree hyrax which is landscaped and well protected in the study area. It confirms that the taxon is still quite common in this department. This also confirms that the taxon is still quite common in this Department. The sites of the Central Nucleus of the classified Lama forest actually include ten stations (Djossa et al., 2012). In contrast, in Atlantic and Couffo, the percentage obtained is less than $7 \%$ since the tree hyrax is now rare.

All these five Departments are strongly associated with Dendrohyrax dorsalis subsp sylvestris because they are all located in the Guinean zone, habitat of this taxon, while habitat of Procavia capensis kerstingi is virtually nonexistent. The sole site of the rock hyrax is located at the northern limit of the Guinean phytogeographic area, at its intersection with the Sudano-Guinean zone. This is the site Kaodji ( $\left.7^{\circ} 25^{\prime} \mathrm{N}\right)$. Beyond this first site of Procavia capensis extends the phytogeographical zone of Sudano - Guinean transition, less humid vast area covered by hills and rock-dwelling formations. This explains the dominance of colonies of rock hyraxes (presence fifteen sites) compared to the sites that host the tree hyrax (5 sites). The locality of Kaodji is probably the southern boundary of this sympatric area which extends until to the latitude of the Penessoulou forest $\left(9^{\circ} 30^{\prime} \mathrm{N}\right)$, which host an ancient tree hyrax site; but only $30 \%$ of the sample population interviewed in this central region (Department of Collines and South of the Departments of Borgou and Donga) recognizes the simultaneous presence of both taxa, while the rock hyrax is mentioned by $100 \%$ of the sampled population. This justifies the offset position of the Departments Collines, Borgou and Donga, closer to the rock hyrax than the tree hyrax on the factorial map (Figure 5). The distance between some hyrax sites trees up to $80 \mathrm{~km}$ found herein, suggests that past sites or present, would remain to be discovered in this vast Sudano -guinean area. Most of these inferred or projected sites are located around and inside of the classified forests of Kouffe Mountains, along the Oueme River and its tributaries. The protected areas are considered in fact to be the "last refuge" of wildlife in Africa (Tehou and Sinsin 2000). These environments are still host much of the dense dry forests and gallery forests, habitats of tree hyrax, as outcrops, granite hills and inselbergs which are habitats of rock hyrax. Thanks to ecotones or habitat diversity (sites Kaodji and Koda), two different kinds of hyraxes can live in the same environment albeit allotopic way as in the Serengeti park in Tanzania (Hoeck 1982, 1989). The localities of Kaodji and Koda host each occupation sites of Procavia capensis and Dendrohyrax dorsalis subsp sylvestris located at 1 to $2 \mathrm{~km}$ from each other. By contrast, heterospecific associations were also mentioned in southern Africa in Heterohyrax brucei (hyrax steppes) and Procavia capensis (Barry and Mundy, 2002; Deniro and Epstein, 1978).

\section{Area of occurrence of tree hyrax:-}

The past and present occurrence areas of the tree hyrax were evaluated in the Guinean zone since sites identification being there almost exhaustive. The occurrence area of Dendrohyrax dorsalis ssp sylvestris was reduced by half in three decades from $8007 \mathrm{~km}^{2}$ (past occurrence area) to $4003 \mathrm{~km}^{2}$ (current occurrence area). This significant loss to the taxon habitat in southern Guinean zone in Benin is comparable to that recorded for the red-bellied monkey (Sinsin et al., 2002). However, the taxon distribution area extends beyond the Guinean zone and much of the Sudano - Guinean transition zone or even South - West of Nigeria. Indeed, the authors had listened to two calls of tree hyrax near to a forest island preserved in the town of Ijebu - Ode (100 km from the border Benin - Nigeria) and whose vocalization has proved to be very similar to that of Benin taxon. Considering the well concordant vocalizations specimens of Ghana and Benin (Akpona et al., 2011), we would be tempted to say that this is the same subspecies represented from Ghana to Nigeria, pending extensive genetic and molecular studies. Those genetic and molecular studies could show discrimination or not in the various subpopulations of D. dorsalis subsp sylvestris of West Africa.

The largest subpopulation of hyraxes trees still probably that of the classified forest of Lama (16250 ha), Central ecosystem whose core is well preserved for several decades. Most other occupancy sites of tree hyrax correspond to smaller forest patches, a few hectares. Occupation sites of less than a hectare were observed in isolated hyraxes groups in Tanzania (Hoeck, 1982). It is not only the classified forests, sacred or community forests usually degraded and used as last refuges by the taxon but also inaccessible gallery forests, swamps and flood forests. Like the redbellied monkey Cercopithecus erythrogaster erythrogaster (Sinsin et al., 2002), the taxon as refuge there probably because these habitats in the Oueme River Valley are generally difficult to access more than half of the year. These small colonies of $D$. dorsalis subsp sylvestris are not spared from a possible local extinction due to their sometimes irreversible isolation from other metapopulation (development of settlements and agricultural systems ....) 


\section{Conclusion:-}

The greatest population recorded in southern Benin and human activities had destroyed and fragmented the habitat of tree hyrax over the last fifty years. This pressure on this taxon has created isolation of its subpopulations of Benin from one another but also from those of Nigeria. Nevertheless, this study reveals the wide geographic distribution of hyraxes in Benin, particularly that of Dendrohyrax dorsalis subsp sylvestris which was omitted from Dahomey Gap until the late 20th century by zoologists. Despite the reduction in its area of half of occurrence in the Guinean zone (preferred habitat), extensive studies on the behavioral ecology, population, habitat, its ethnozoology and genetic characterization, will better reflect its real status. This is indeed a prerequisite for the development of a conservation program that may be accompanied by a conservation strategy of Dendrohyrax dorsalis subsp sylvestris species which is the least prolific species of three kinds of hyraxes.

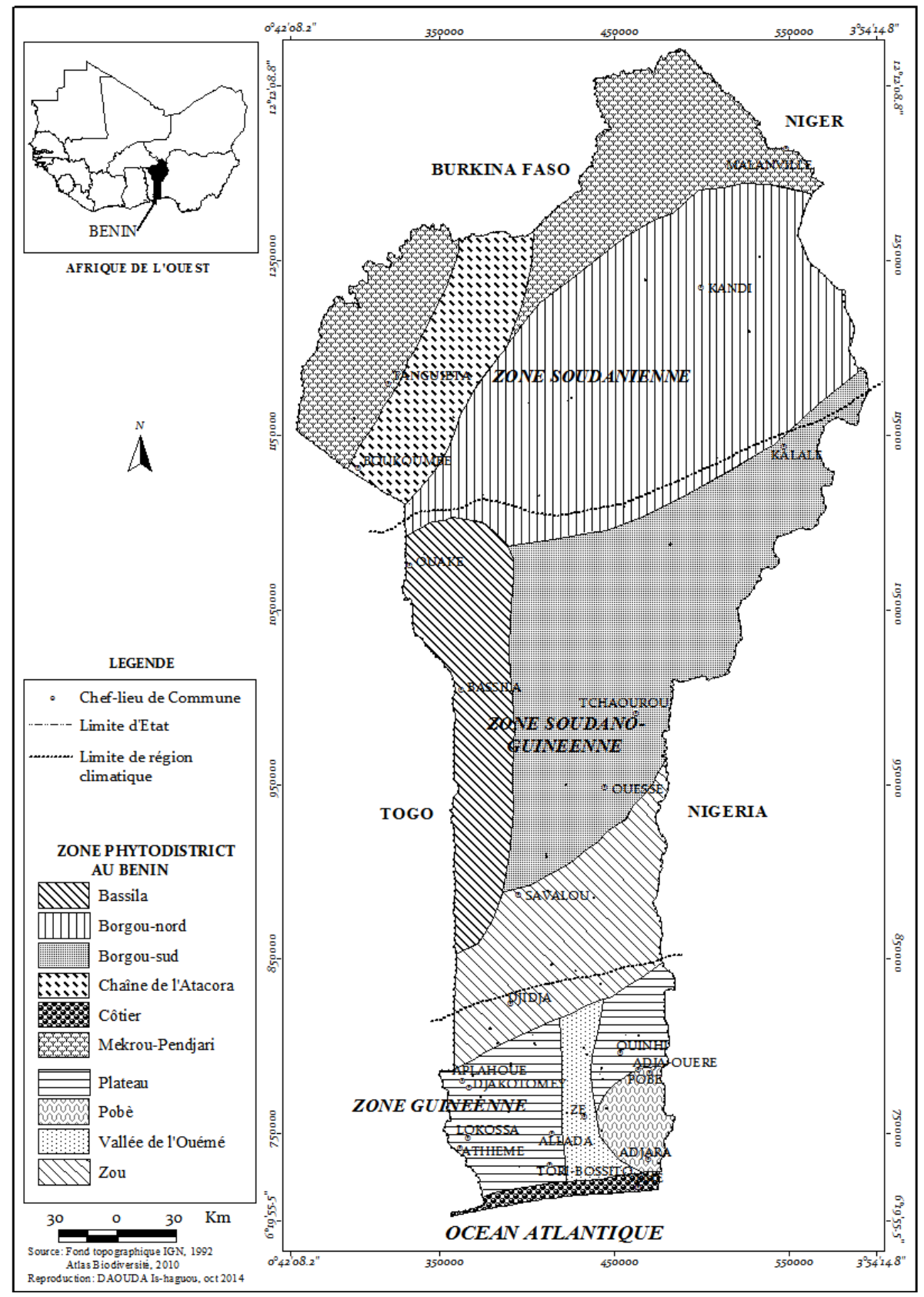

Figure 1:- phytogeographic Districts of Benin (Source : Neuenschwander et al., 2011) 


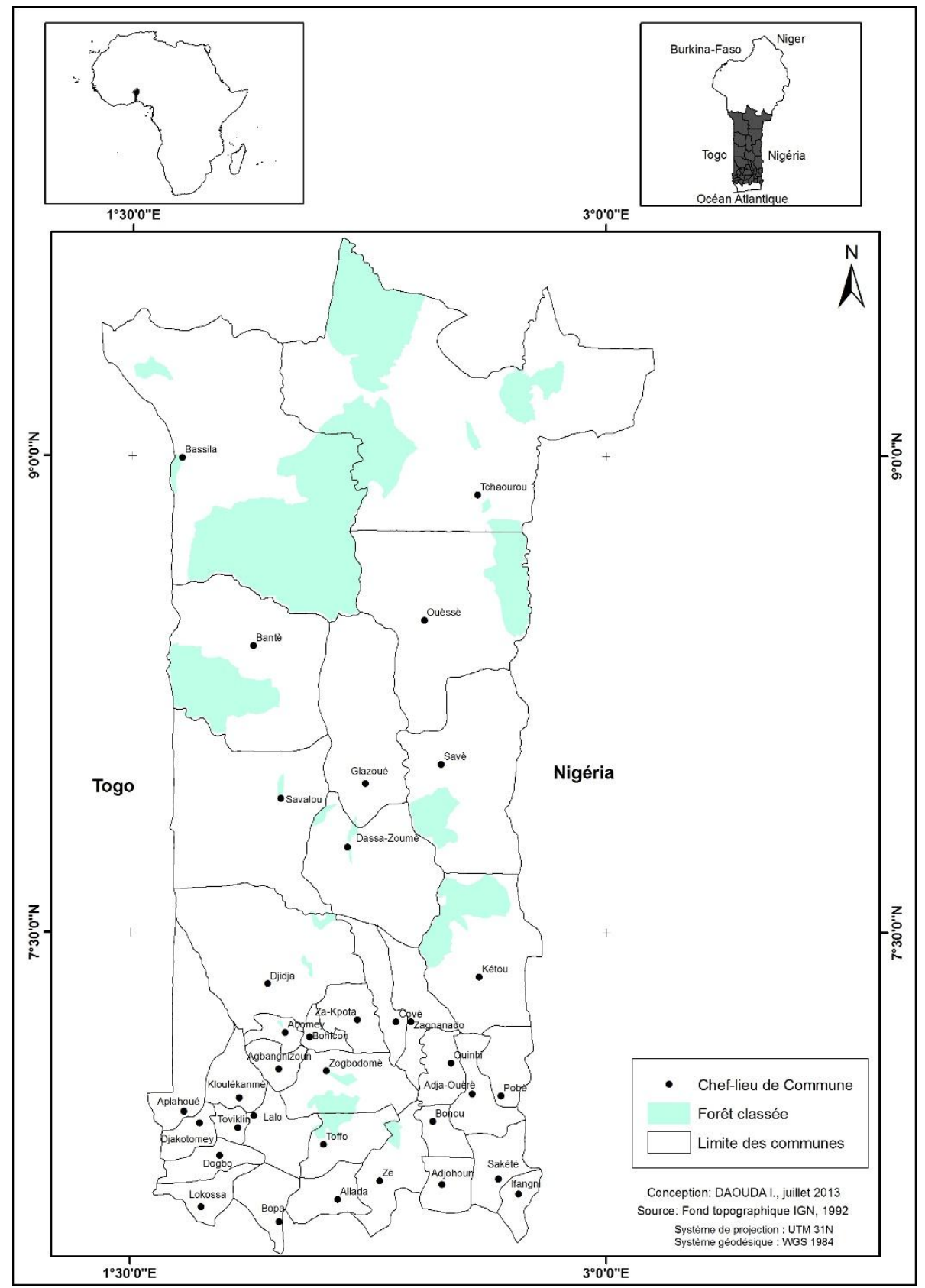

Figure 2: Study area and surveyed Communes in the South and Central regions of Benin for hyraxes study. 


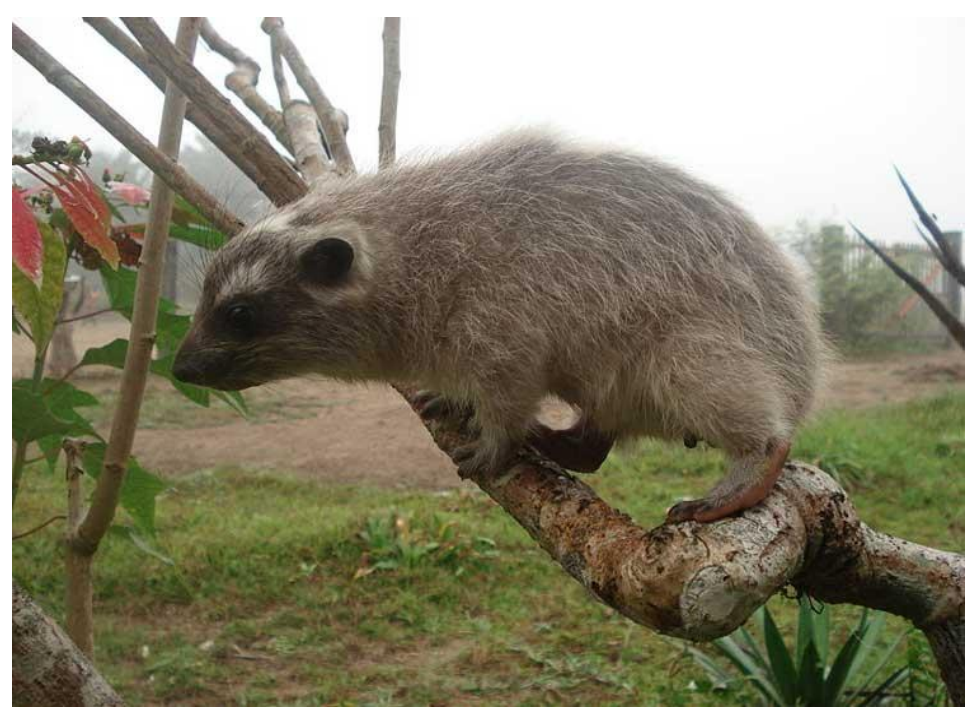

Figure 3: Dendrohyrax dorsalis (Fraser, 1855)

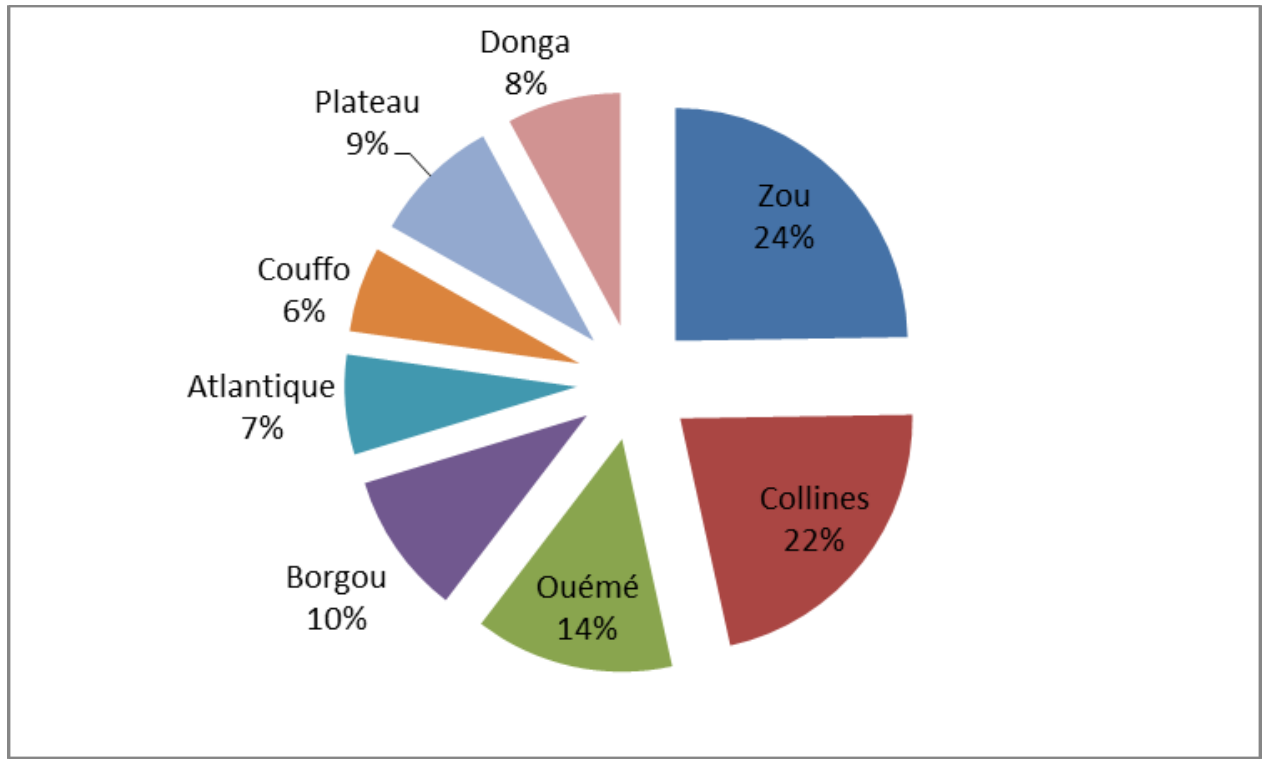

Fig. 4:- Relative Contribution of each administrative Department to the survey database on the hyraxes. 
MCA factor map

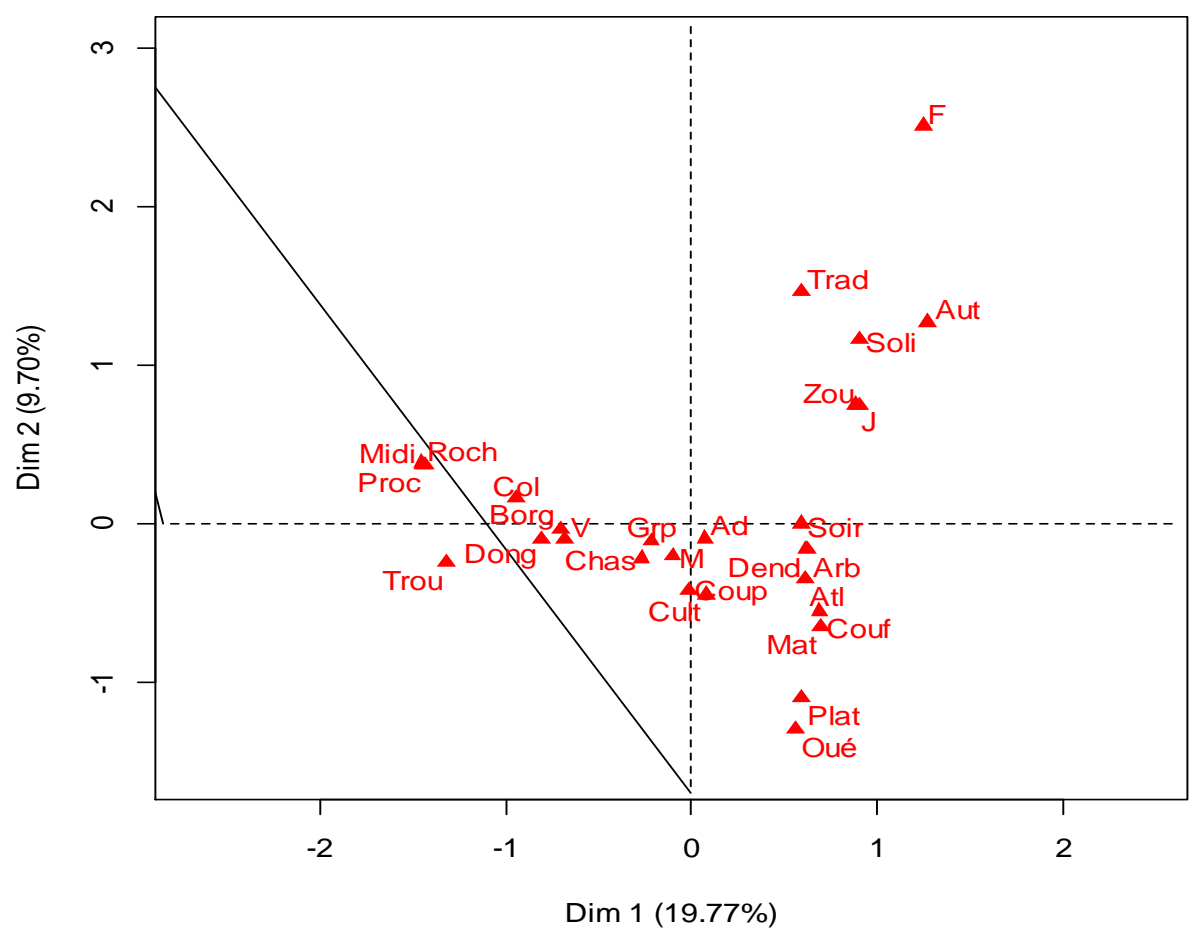

Figure 5: Factorial Map on hyraxe species identification according to their habits, interviewees occupation and their provenance (department). 


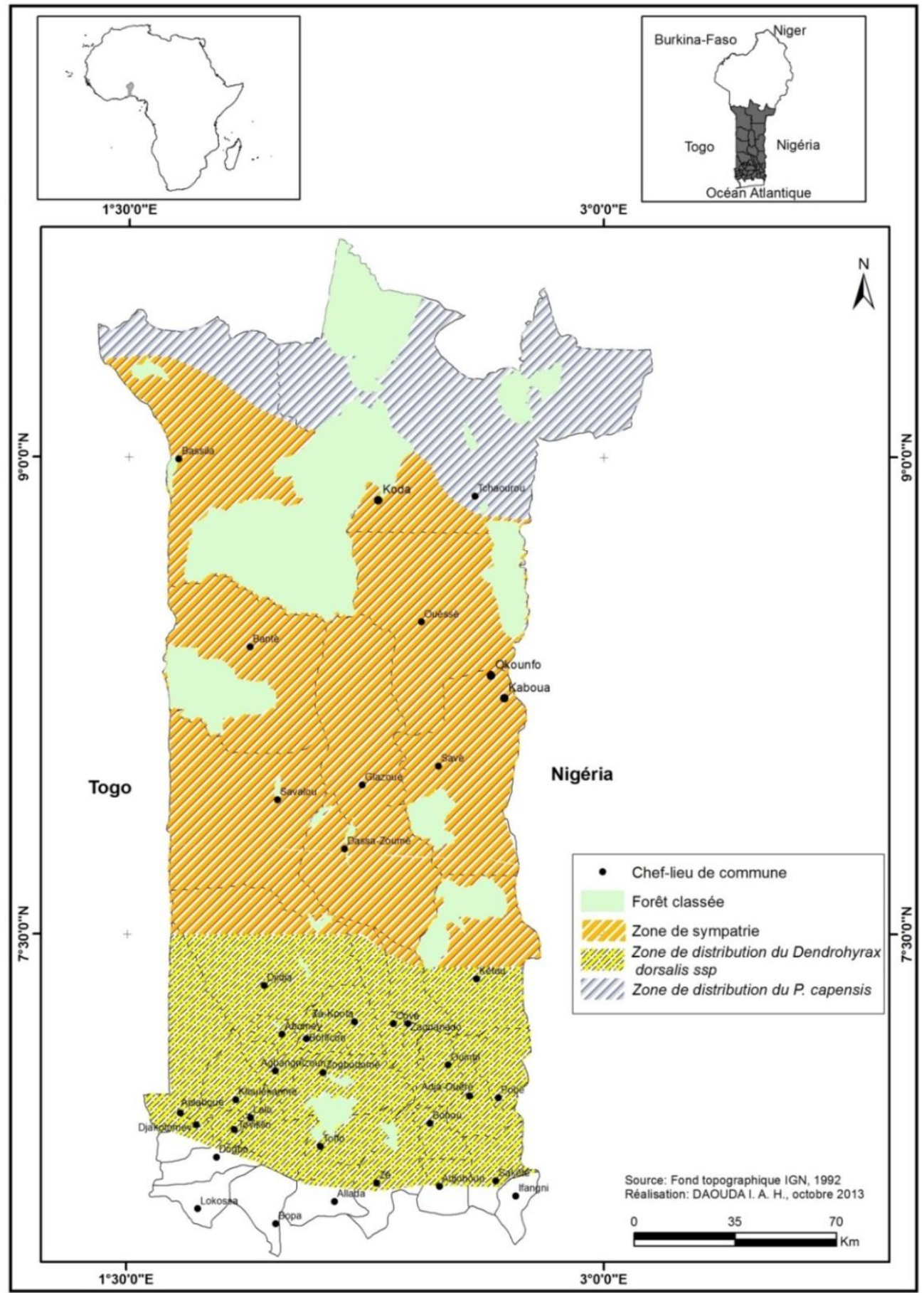

Figure 6: Geographical boundaries of the distribution area (known or inferred, past and present) of hyrax in the study area. (Years 1961-2011): first phase of the study. 


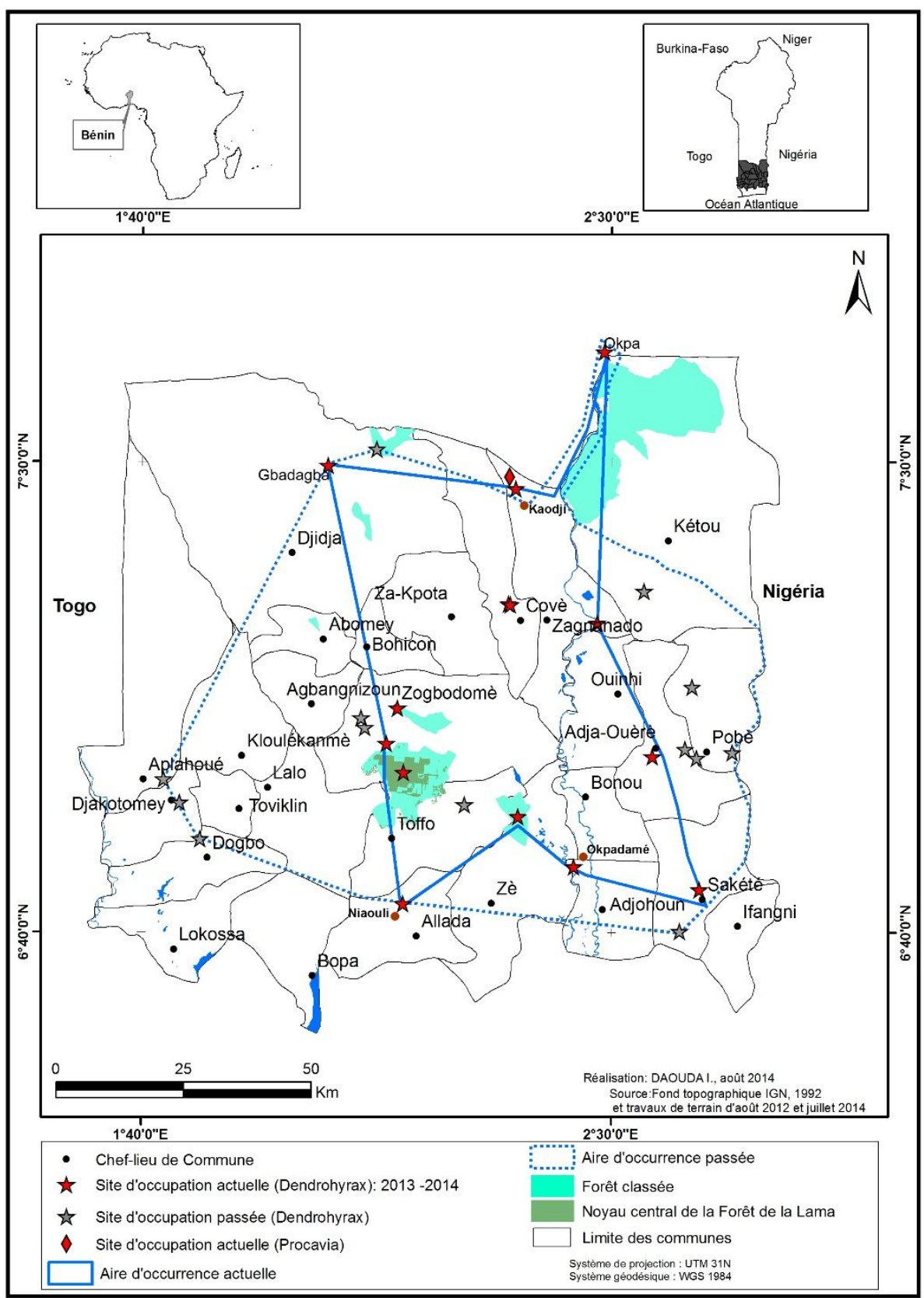

Figure 7: Past and present occurrence areas of the tree hyrax in the South Benin (Guinean Zone). 


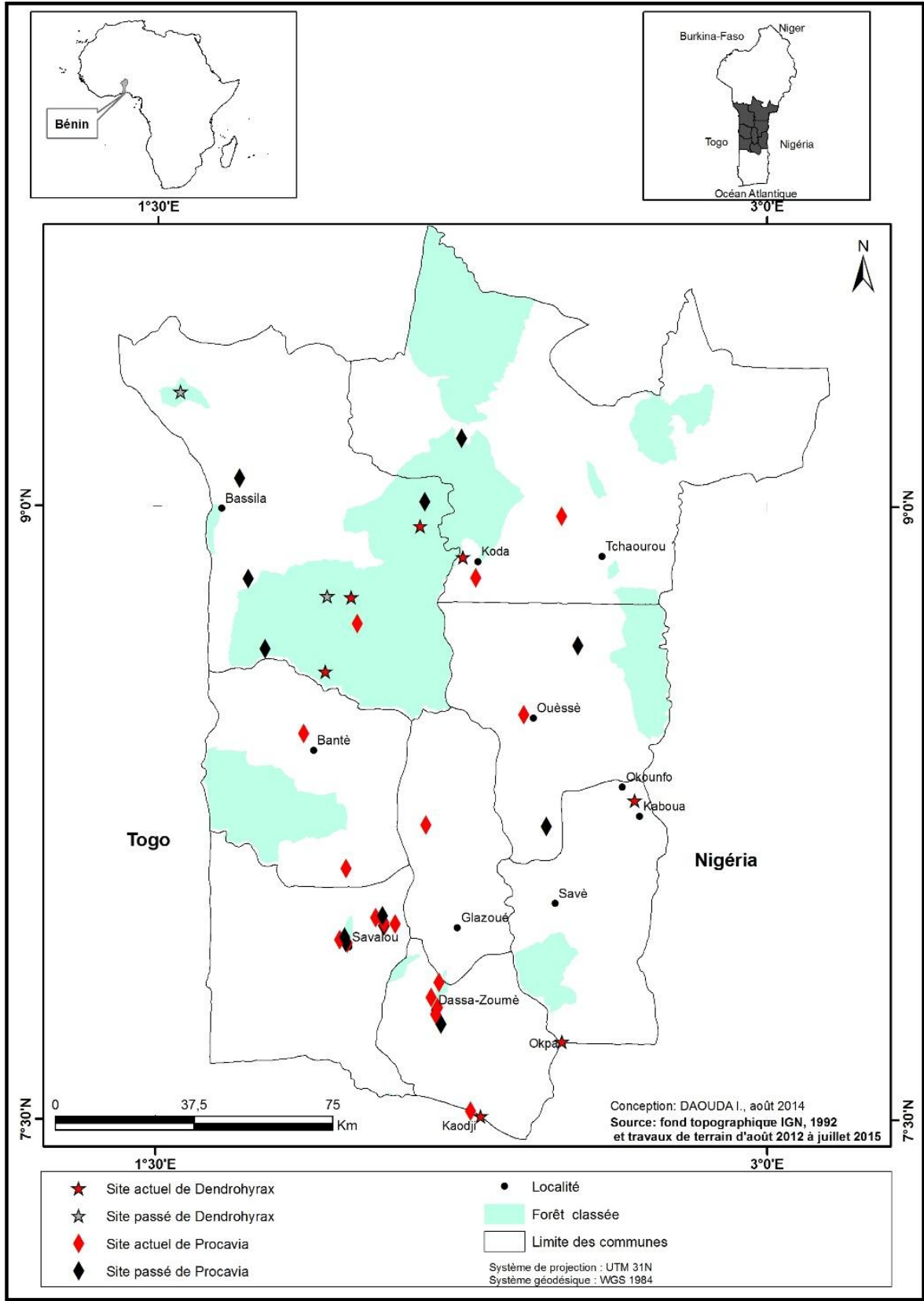

Figure 8: past and present sites of hyrax in the sympatric zone entirely within the Sudano - Guinean (Central regions of Benin). 
Table 1: Variables used for multivariate analysis, with their respective terms

\begin{tabular}{|c|c|}
\hline Variables & Terms \\
\hline Departments & $\begin{array}{l}\text { Atlantic (Atl), Borgou (Borg), Collines (Col), Couffo (Couf), Plateau (Plat)*, Zou } \\
\text { and Oueme (Oue) }\end{array}$ \\
\hline Age & Young $(\mathrm{J} ;<25$ years $) ;$ Adult $(\mathrm{Ad} ; 25 \leq$ age $<60) ;$ Old $(\mathrm{V} ; \geq 60$ ans $)$ \\
\hline Sex & Male $(\mathrm{M})$; Female $(\mathrm{F})$ \\
\hline Main activity & Hunter (Chas), Farmer (Cult), Traditionnal therapist (Trad), Other (Aut) \\
\hline Observation moment & $\begin{array}{l}\text { Morning** (At dawn), Noon*** ( } 09 \text { o'clock to } 17 \text { o'clock), evening ( } 18 \text { o'clock to } \\
21 \text { o'clock) }\end{array}$ \\
\hline Observation localisation & Rock (Roch); Tree (Arb); \\
\hline Type of observed hyrax & Dendrohyrax (Dend); Procavia (Proc) \\
\hline Life style or habits & Loner (Soli); Couple (Coup) ; Group (Grp) \\
\hline
\end{tabular}

Table 2: Sites and localities where Dendrohyrax dorsalis ssp still exists and whose presence was confirmed by authors from 2012 to 2013.

\begin{tabular}{|c|c|c|c|}
\hline $\begin{array}{l}\text { Localities or Sites of curre } \\
\text { occupation: 2012-2014 }\end{array}$ & Communes & $\begin{array}{l}\text { Ecology: phytogeographi } \\
\text { district }\end{array}$ & Occupied habitats \\
\hline Classified Forest of Lama & $\begin{array}{l}\text { Zogbodome a } \\
\text { Toffo }\end{array}$ & $\begin{array}{l}\text { 'District of PLATEAY } \\
\text { depression of Lama }\end{array}$ & Dense and semi-deciduous Forest \\
\hline Tovlamè & Zogbodomè & 'District of PLATEAU' & Border of stream \\
\hline Gbadagba & Djidja & $\begin{array}{ll}\begin{array}{l}\text { 'District of } \\
\text { degraded Forest }\end{array} & \text { ZOU } \\
\end{array}$ & Border of stream \\
\hline Cove & Cove & $\begin{array}{l}\text { 'District of PLATEAI } \\
\text { degraded Forest }\end{array}$ & Border of stream \\
\hline Kaodji $\left(7^{\circ} 25\right.$ & Zagnanado & \begin{tabular}{lll|}
$\begin{array}{l}\text { District } \\
\text { degraded Forest }\end{array}$ & PLATEAY \\
\end{tabular} & $\begin{array}{l}\text { Border of stream (sympatric ar } \\
\text { with P. Capensis) }\end{array}$ \\
\hline Forest of Itchede & Adja-Ouere & $\begin{array}{lcc}\text { 'District of } & \text { PLATEAU } \\
\text { Classified Forest } & \\
\end{array}$ & Border of stream \\
\hline $\begin{array}{ll}\text { Classified } & \text { Forest } \\
\text { Sakete (Gbamè) } & \end{array}$ & Sakete & 'District of POBE' Depression & $\begin{array}{l}\text { Semi deciduous and } \\
\text { dense Forest }\end{array}$ \\
\hline (Akpadanou) & Adjohoun & 'OUEME VALLEY : & Periodically flooded gallery fores \\
\hline Okpa & Savè & 'District of ZOU : gallery fores & $\begin{array}{l}\text { Periodically flooded gallery for } \\
\text { (Oueme stream border) }\end{array}$ \\
\hline Niaouli & Allada & District of PLATEAU & $\begin{array}{l}\text { Semi deciduous and } \\
\text { dense Forest }\end{array}$ \\
\hline Zè-Aokpa & Zè & District of PLATEAU & Degraded Forest \\
\hline
\end{tabular}

Table 3: Sites and localities where Dendrohyrax dorsalis subsp sylvestris still exists (in Sudano-Guinean zone) and confirmed by the authors: 2013-2015.

\begin{tabular}{|l|l|l|l|}
\hline $\begin{array}{l}\text { Localities or Sites of curre } \\
\text { occupation: 2012-2014 }\end{array}$ & Commun & Ecology: phytogeographical district & Occupied habitats \\
\hline Okounfo & Save & $\begin{array}{l}\text { Soudano-Guinean transition Zone (Distr } \\
\text { of Zou) }\end{array}$ & Border of Oueme stream \\
\hline Koda & Tchaouro & $\begin{array}{l}\text { Soudano-Guinean transition Zone Distr } \\
\text { of Zou (South Borgou) }\end{array}$ & Border of stream \\
\hline Baanon & Bantè & $\begin{array}{l}\text { Soudano-Guinean transition Zone } \\
\text { District of Zou (South Borgou) }\end{array}$ & Border of stream Adjiro \\
\hline Ouanou & Bassila & $\begin{array}{l}\text { Soudano-Guinean transition Zone } \\
\text { District of Zou (South Borgou) }\end{array}$ & Degraded Forest \\
\hline $\begin{array}{l}\text { Sites of Kouffe Mounta } \\
\text { Forest }\end{array}$ & Bassila & $\begin{array}{l}\text { Soudano-Guinean transition Zone } \\
\text { District of Zou (South Borgou) }\end{array}$ & Degraded Forest \\
\hline
\end{tabular}




\section{Referrences:-}

1. Akpona, A.H., Djossa, B. and Sinsin, B. (2011). Damans/Hyraxes, pp 304-307. In Neuenschwander P., Sinsin, B. and Goergen, G. (eds). 2011. Protection de la Nature en Afrique de 1'Ouest: Une Liste Rouge pour le Bénin. Nature Conservation in West Africa: Red List for Benin. International Institute of Tropical Agriculture, Ibadan, Nigeria, 365 pages.

2. Batcho, A.K. (2004). Contribution à l'étude de l'écologie du daman de rocher (Procavia capensis Pallas 1766) dans les communes de Dassa-Zoume et de Glazoué. Mémoire DIT-CPU. Univ. Nat. Du Bénin, Abomey-Calavi, $73 \mathrm{pp}$.

3. Barry, R. E. and Mundy, P. J. (1998). Population dynamics of two species of hyraxes in the Matobo National Park, Zimbabwe

4. Codjia, J.T.C., Capanan, E., Civitelli, M.V. and Bizzoco, D. (1996). Les chromozomes de Mastomys natalensis et Mastomys erythroleucus (Rongeurs, Muridae) du sud-Bénin (Afrique de l'Ouest) : Nouvelles précisions sur la variabilité chromosomique. Mammalia 60 n²: 299-303.

5. Colyn, M., Hulselmans, J., Sonet, G., Oudé, P., De Winter, I., Natta, A., Tamás Nagy, Z. and Verheyen, E. (2010). Discovery of a new duiker species (Bovidae: Cephalophinae) from the Dahomey Gap, West Africa. Zootaxa 2637: 1 - 30. ISSN 1175 - 5326 (Print edition) ISSN 1175 - 5334 (online edition)

6. Daouda, I.A.H. (2002). Caractéristiques Staturo - Pondérales, Parasitisme par les Cestodes et Dynamique de Population chez les Rongeurs de la Presqu'île du Cap - Vert (Sénégal). Th. de Doctorat de Troisième Cycle. UCAD, 130 p. Dakar, Sénégal.

7. Deniro, M.J. and Epstein, S. (1978). Carbone isotopic evidence for different feeding pattern in two hyrax species occupying the same habitat. Science 201 (4359) PP. $906-908$.

8. Granjon, L., Bâ, K., Daouda, I.H. and Duplantier, J.M. (2005). New data on chomosomes from Murid of Benin - The karyotype of Myomys durooi. Mammalia, 69 (3-4) 421-426.

9. Grubb P. 1998. Mammals of Ghana, Sierra Leone and the Gambia. Trendrine (St.Ives) UK 265p

10. Hoeck, H.N. (1982). Population dynamics, dispersal and genetic isolation in two species of hyrax (Heterohyrax brucei and Procavia johnstoni) on Habitat Island in the Serengeti. Ethology: International Journal of Behavioural Biology. Vol. 59 (3) : $177-210$.

11. Hoeck, H.N. (1989). Demography and Competition in Hyrax - A 17years study. Oecologia 79 (3): 353 - 360.

12. IUCN (2013). IUCN Red List of Threatened Species. Version 2013. 1. Site Internet : 〈www.iucnredlist.org> téléchargé le 27 octobre 2013.

13. Kingdon, J. (1997). The Kingdon field guide to African Mammals. Academic Press, London 450p

14. Kingdon, J. (2006). Guide des Mammifères d'Afrique. The Kingdon field guide to African Mammals. Academic Press, London 450p

15. Nobime, G. and Sinsin, B. (2003). Les strategies de survie du singe à ventre rouge Cercopithecus erythrogaster erythrogaster dans la forêt classée de la Lama au Bénin. Biogeographica 79 (4) : 153 - 166.

16. Sinsin B. and Kampmann, D. (2010). Atlas de la Biodiversité de l'Afrique de l'Ouest. Tome 1: Bénin, Cotonou and Frankfurt, Main. $726 \mathrm{p}$

17. Sinsin, B., Nobime, G., Téhou, A., Bekhuis, P. and Tchibozo, S. (2002). Past and present distribution of the Red - Bellied Monkey Cercopithecus erythrogaster erythrogaster in Benin. Folia Primatology. 73: 116 - 123.

18. Neuenschwander, P., Sinsin, B. and Goergen, G. (2011). Protection de la Nature en Afrique de l'Ouest : Une Liste Rouge pour le Bénin. Nature Conservation in West Africa : Red List for Benin. International Institute of Tropical Agriculture, Ibadan, Nigeria, 365 pages.

19. UICN (2012a). Catégories et Critères de la Liste rouge de l'UICN : Version 3.1.

20. Deuxième édition. Gland, Suisse et Cambridge, Royaume-Uni : UICN. vi + 32pp.

21. Originalement publié en tant que IUCN Red List Categories and Criteria: Version 3.1.

22. Second edition. (Gland, Switzerland and Cambridge, UK: IUCN, 2012).

23. UICN (2012b). Lignes Directives pour l'Application des Critères de la Liste Rouge de l'UICN aux niveaux Régional et National. Version 4.0. Gland, Suisse et Cambridge, Royaume - Uni : 44 pp

24. UNEP-WCMC (2003). Checklist of mammals listed in the CITES appendicies and in EC Regulation $338 / 97.6^{\text {th }}$ edition. JNCC Repport 342, 213 pp. 